\title{
Challenges on modelling a large river basin with scarce data: A case study of the Indus upper catchment
}

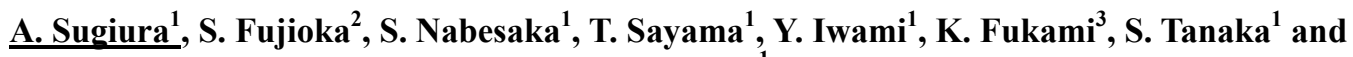 \\ K.Takeuchi ${ }^{1}$ \\ ${ }^{1}$ Water-related Hazard Research Group International Centre for Water Hazard and Risk Management \\ (ICHARM), PWRI, 1-6,Minamihara, Tsukuba, Ibaraki 305-8516, Japan Tel +81-29-879-6809, \\ Fax +81-29-879-6709 \\ ${ }^{2}$ Japan Water Agency \\ ${ }^{3}$ National Institute for Land and Infrastructure Management (NILIM), \\ Ministry of Land, Infrastructure, Transport and Tourism (MLIT) \\ sugiura55@pwri.go.jp
}

\begin{abstract}
Pakistan's unprecedented floods of 2010 highlighted the possible contribution of Indus upper catchment hydrological modeling to flood risk assessment. However, this modeling is an extremely challenging exercise because of the lack of hydrometeorological data, which are difficult to collect due to the geography of the catchment (the highest point is over $7500 \mathrm{~m})$. Indeed, in the study area $\left(133,300 \mathrm{~km}^{2}\right)$, there are 24 rain gauges collecting sufficient daily data, which leads to an average area of Thiessen polygons well over (by 10 times) the WMO minimum density network requirements of $250 \mathrm{~km}^{2}$ for hilly area. The lack of local data for soil and aquifer is another challenge. Despite those limitations, IFAS (Integrated Flood Analysis System) was run to conduct rainfall runoff analysis from the very upstream (in India and China) to Taunsa (midstream Indus in Pakistan). A $30 \mathrm{sec}$ Digital Elevation Model based on GlobalMap Elevation from ISCGM was upscaled to a $5 \mathrm{~km}$ grid model. The runoff analysis engine of IFAS is based on a 3-layered spatially distributed tank model. The 24 rain gauges daily precipitation, 9 discharges at river stations, barrages and dams and NCEP reanalyzed latent heat fluxes were considered as input data. Global datasets for land cover (GlobalMap Land cover, ISCGM) and soil textural types and depths (FAO/UNESCO DHSM) were used for parameterization. The upper catchment was divided into sub-basins and calibration conducted independently for each of them. As simulated discharges for mid-lower stream sub-basins were more reasonable than for more upstream sub-basins, parameters calibrated in the mid-lower sub-basins were applied to the upstream ones. Then, the calibration process was conducted for three flood events $(1988,1997$ and 2010). Finally, in order to validate the parameters and the model, Nash-Sutcliff efficiencies, $E_{N S}$, were calculated for discharges simulated for three other flood events (1992, 1994 and 2012). In average, $E_{N S}$ were over 0.80 at seven river stations and the model was considered well-calibrated.
\end{abstract}

Keywords: Flood, hydrological modeling, large river basin, Indus, Pakistan, IFAS (Integrated Flood Analysis System). 
Sugiura et al., Challenges on modelling large river basin with scare data availability: case study of Indus upper catchment.

\section{INTRODUCTION}

Flood occurs frequently in the Indus River Basin due to heavy rainfall during the monsoon season (JulySeptember), which is exacerbated sometimes with increased snowmelt contribution to discharge (Inam et al. 2007, FFC, 2013). After 2010's unprecedented floods in Pakistan, Pakistani authorities highlighted the need to develop improved flood forecasting models (FFC, 2013). This research is part of the "Strategic Strengthening Flood Forecasting and Management Capacity in Pakistan" implemented by UNESCO from January 2012 and this research's final goal is the development of a comprehensive flood forecasting system. This paper focuses on the development of a hydrological model using the physically distributed rainfallrunoff model (Public Work Research Institute - Distributed Hydrological Model, 3-layer tank PWRI-DHM) mounted in IFAS (Integrated Flood Analysis System) on mainstream Indus from its source to mid-stream Taunsa $\left(133,300 \mathrm{~km}^{2}, 37 \%\right.$ of the whole river basin, Fig. 1a) and the verification of its reproducibility for 6 past flood events. In order to do so, and based on the fact of lack of data availability, on the day order of magnitude lead-time between the different stations of the basin at which forecast and flood alert are issued, the study area was divided into 6 sub-basins, calibrated separately using discharges of upstream stations as boundary condition. The objective of this paper is to present the adopted methodology to develop a calibrated hydrological model and verify its reproducibility despite the lack of data in the Indus river basin. Snowmelt contribution to discharge is only considered indirectly by giving boundary condition and snowmelt component modeling is out of the scope of this paper as well as the assessment of the model itself.

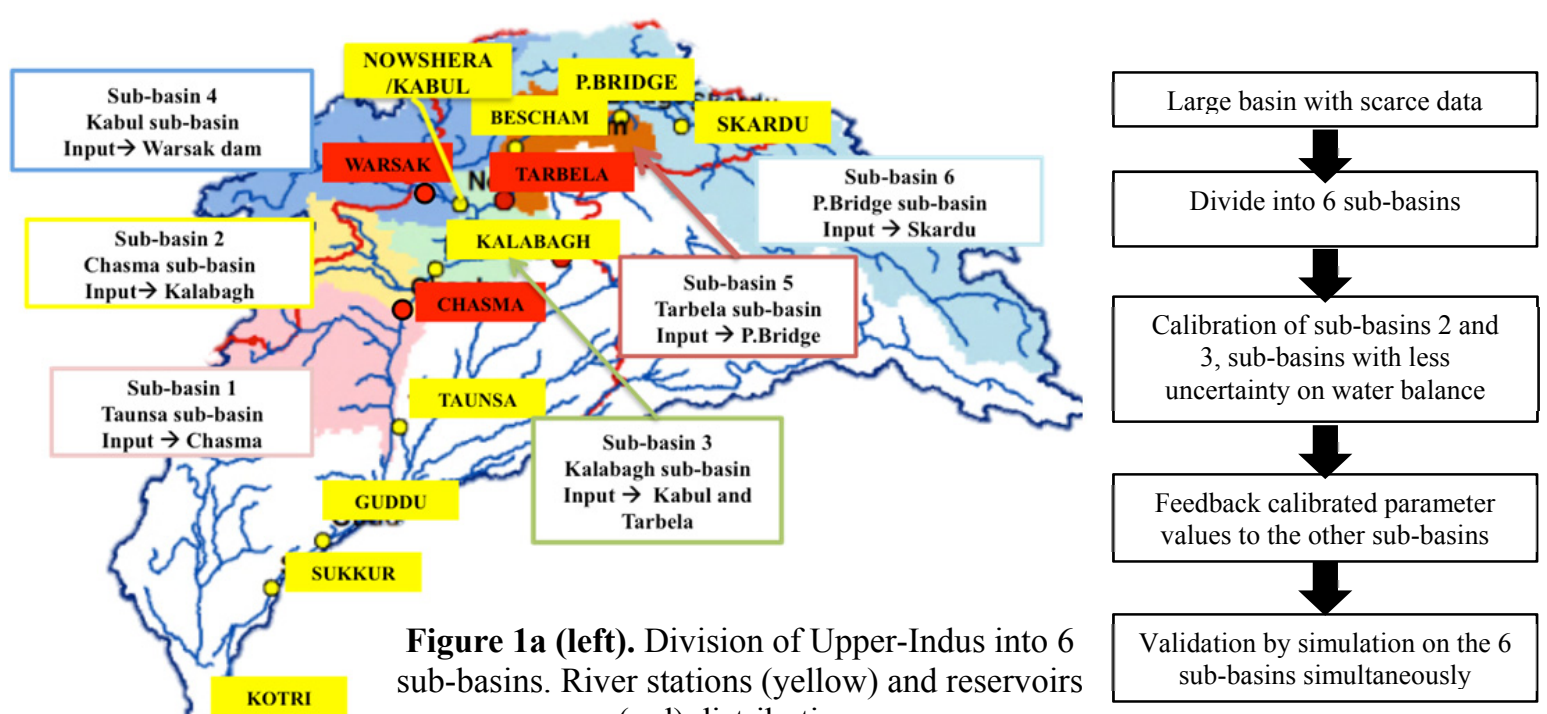

Figure 1 b (right). Adopted methodology

\section{DATA AVAILABILITY IN THE TARGET AREA}

The Indus River system takes its source at $5182 \mathrm{~m}$ in Tibet (Inam et al. 2007) and crosses India, Afghanistan to reach the Arabian Sea in Pakistan where it mostly lies (FAO 2011). The Indus River basin comprises the Western rivers, Indus mainstream with its tributaries like Shyok, Shigar, Gilgit and Kabul and Jhelum, and the Eastern Rivers, Chenab, Ravi, Beas and Sutlej (Inam et al. 2007). This section describes the data availability, firstly, concerning rainfall data, following a consistency test comparing measured rainfall data from different sources in Pakistan (not reported in this study), PMD (Pakistan Meteorological Department) daily rainfalls data were selected as the most reliable source of measured rainfall. Hence, PMD daily rainfall data collected from 03:00 to 03:00 GTM were also the only complete source available and were therefore chosen as the input data for both calibration and validation processes. Fig. 2 describes PMD rain gauges and meteorological stations' distribution over Pakistan. The number of stations for which data are available varies from year to year, illustrating the effort of PMD to develop an operational meteorological data network with the number of stations almost tripled from 36 to 92 between 1988 and 2012 over the whole river basin in Pakistan. Secondly, reference evapotranspiration $\mathrm{ET}_{\mathrm{o}}$ (FAO-Penman-Monteith, (Allen et al. 1988)) can be calculated at 18 PMD meteorological stations in the whole Indus river basin. There are two areas with no measured evapotranspiration even after distributing ET $_{0}$ using Thiessen polygons (Fig. 2, circles). Therefore, National Centres for Environmental Predictions (NCEP) latent heat net fluxes, available globally, were 
Sugiura et al., Challenges on modelling large river basin with scare data availability: case study of Indus upper catchment.

chosen as an estimator of evapotranspiration. NCEP latent heat net fluxes daily mean value $\left(\mathrm{W} / \mathrm{m}^{2}\right)$ are available monthly, at $1.9^{\circ}$ grid, from $88.542 \mathrm{~N}-88.542 \mathrm{~S}, 0 \mathrm{E}-358.125 \mathrm{E}$ and are calculated from 30 years data (1979-2009) (Kanamitsu et al. 2002). Thirdly, 6 hourly measured discharges provided by WAPDA (Water and Power Development Authority, Pakistan) at the following seven stations' discharges were considered: Partab Bridge, Besham, Nowshera, Tarbela, Kalabagh, Chasma and Taunsa (refer to discharge stations in Fig. 2). In addition, discharges data for Skardu, the most upstream station and for Warsak dam, in the upstream of Nowshera station were also included as boundary conditions. Fourth, at present, available soil hydraulic properties data do not cover the whole target area. Data collected so far are very localized like Kelleners et al. (1999) studying soil hydraulic properties for unsaturated zone around Faisalabad in Punjab province.

In summary, both local PMD evapotranspiration and soil hydraulic properties data are found to be very limited and it is necessary at this stage to rely on global datasets and PMD daily rainfall data distributed using Thiessen polygons, NCEP reanalysis 2 data for latent heat net fluxes and FAO/UNESCO globally available soil type distribution map (FAO, 2009) were selected as default input data.

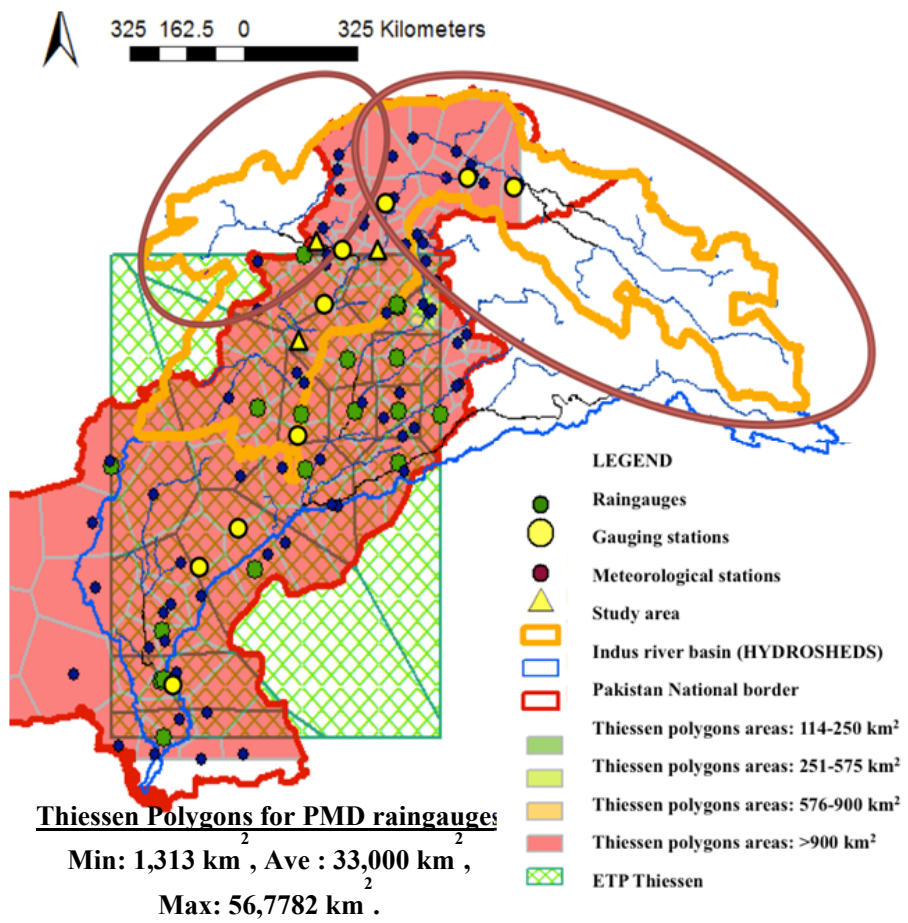

Table 1 Description of the 3layer model PWRI-DHM

\begin{tabular}{|c|c|}
\hline Model & Function \\
\hline $\begin{array}{c}\text { Surface tank } \\
\text { model }\end{array}$ & $\begin{array}{c}\text { Infiltration to } \\
\text { unsaturated layer, } \\
\text { surface runoff, surface } \\
\text { storage, } \\
\text { evapotranspiration, } \\
\text { rapid unsaturated } \\
\text { subsurface flow }\end{array}$ \\
\hline $\begin{array}{c}\text { Subsurface } \\
\text { tank model (for } \\
\text { the 3 tank } \\
\text { model) }\end{array}$ & $\begin{array}{c}\text { Infiltration to aquifer, } \\
\text { subsurface runoff, } \\
\text { subsurface storage, } \\
\text { slow unsaturated } \\
\text { subsurface flow }\end{array}$ \\
\hline $\begin{array}{c}\text { Aquifer tank } \\
\text { model }\end{array}$ & $\begin{array}{c}\text { Outflow from aquifer, } \\
\text { aquifer loss }\end{array}$ \\
\hline $\begin{array}{c}\text { River tank } \\
\text { model }\end{array}$ & \begin{tabular}{c} 
River course discharge \\
\hline
\end{tabular} \\
\hline
\end{tabular}

Figure 2 Rain gauges, meteorological stations, discharge stations, reservoirs distribution. Thiessen polygons areas in $\mathrm{km}^{2}$ (mostly red or over $900 \mathrm{~km}^{2}$ for rain gauges, green dash for ETP). Circles indicate territories without any coverage of rain gauges: Kabul river basin and very upstream Indus.

\section{METHODOLOGY}

\subsection{PWRI-DHM in IFAS 3-layer tank model parameterization}

PWRI-DHM is based on Sugawara et al (1956) tank model concept used in a distributed and 3-layer tank configuration. The 3 layers are (Fig 3 and Table 1): firstly, a surface layer tank presenting a set of parameters replicated into land use classes based on GlobalMap Land cover (ISCGM) $30 \mathrm{sec}$ resolution) categories grouped into five classes of parameters according to land use (1) forest and woodland, 2) shrubs, herbaceous or bare land, 3) cropland, paddy field, and wetland, 4) urban and 5) snow/ice and water bodies). Second, an unsaturated layer tank and an aquifer layer tank presenting a set of parameters replicated into soil textural classes, which flows go directly or indirectly to the river routing model in the river tank presenting a set of 10 parameters, with in total 130 parameters to tune. Details are available in Sugiura and al. (2010) for IFAS and Fujita and al. (2006) for the 3-layer tank model. In this study, a 5-km mesh model was set up. The parameterization was performed by trial and error for the surface tank by essentially tuning infiltration capacity, maximum storage height, surface roughness coefficient, for the aquifer tank by essentially tuning slow intermediate flow regulation coefficient and base flow coefficient and river tank by essentially tuning Manning's roughness coefficient, those parameters being the most sensitive (Fukami et al. 2009). For the 
Sugiura et al., Challenges on modelling large river basin with scare data availability: case study of Indus upper catchment.

unsaturated tank, all parameters were fixed according to Maidment (1993) hydraulic properties corresponding to soil textural classes. Moreover, for the most northern area of the Indus river basin, two uncertainties had to be overcome, firstly, the lack of measured rainfall data and secondly, the fact that precipitations for this high elevation part (over $7000 \mathrm{~m}$ elevation for some parts) are snowfall and not rainfall. But snowfall estimates and snowmelt modeling are not in the scope of this project. Hence, the solution retained was first to divide the study area into six sub-basins (Fig 1a). Then, for each sub-basin, upstream station discharges were given as the boundary conditions and simulated discharges were compared to measured discharge at the outlet (downstream) of each sub-basin for calibration and validation. By giving measured discharge as boundary conditions, it was expected to account indirectly for snowmelt runoff. Hence, at Skardu, Partab Bridge and Nowshera river stations, discharges were input to compensate the lack of rain/snowfall and snowmelt data. To take in account Warsak, Tarbela dams and Kalabagh, Chashma, Taunsa barrages operation, outflows measured at those points were also given as boundary conditions. Therefore, the discharges between the following points were simulated: between Skardu and Partab Bridge (Sub-basin 6), Partab Bridge and Tarbela (Sub-basin 5), Tarbela and Kabul (Sub-basin 4), Kabul, Tarbela and Kalabagh (Sub-basin 3), Kalabagh and Chashma (Sub-basin 2), then Chashma and Taunsa (Sub-basin 1).

\subsection{Characteristics of the six sub-basins}

The study area covered represents $133,300 \mathrm{~km}^{2}$ and was divided into 6 sub-basins according to the following characteristics (Fig 1a). Sub-basins 1 and 2 characteristics are the absence of rain gauges on part of their area and the limited number of meteorological stations. Sub-basin 3 is characterized by a greater by yet insufficient number of rain gauges (minimum of $1812 \mathrm{~km}^{2}$ per station, maximum of $9958 \mathrm{~km}^{2}$ per station and an average of $4791 \mathrm{~km}^{2}$ per station, all over the recommended minimum number of non-recording rain gauge network of $250 \mathrm{~km}^{2}$ for mountainous area (WMO 2008), an insufficient number of meteorological stations and because of the presence of Tarbela dam, an accurate water balance. Sub-basins 4, 5 and 6 (Fig 2, circles) characteristics are the absence of rain gauges on most of their area, the absence of meteorological station, and a significant contribution of snowmelt in their discharges (Inam et al. 2007).

Because of the principle of equifinality, one can always find different sets of parameters giving good fits with observed data (Beven and Freer 2001). However, if we want our model to keep somehow its physically distributed characteristics, calibration should take place where uncertainty is smaller. In our case, Tarbela and Chasma dams present more reliable inflow and outflow data than at barrages. Moreover, the numbers of hydrometeorological data are more widely available in the mid-downstream part of the target area. Therefore, calibration was performed on sub-basins 2 and 3 as explained in section 3.1 and their tuned parameter values fed back to the other sub-basins. Moreover, the aim of this modeling is that this is to be used as part of a flood forecasting system; therefore, the calibration needs to be performed for different magnitude of floods. Therefore, considering also data availability and because 1998, 1992, 1994, 2010, 2011 and 2012 were severe flood years (FFC 2013), with 2010 being an extreme flood year, the three flood events $(1988,1997,2010)$ were considered for calibration and three others for validation $(1992,1994,2012)$.

Moreover, because lead times in the Indus river basin can be counted in days, for instance lead time of 24 hours between P. Bridge and Tarbela, $26 \mathrm{~h}$ between Tarbela and Kalabagh, 51-72 hours between Chasma and Taunsa (Flood Forecasting Division website), this configuration using upstream sub-basin measured discharge as boundary condition to minimize uncertainty on a given sub-basin would still allow to forecast discharges downstream.

\section{RESULTS AND DISCUSSION}

\subsection{Results of hydrological modeling efficiency for each sub-basin for calibration and validation when intermediate measured discharges are set as boundary conditions or not.}

Nash-Sutcliffe Efficiency ( $E_{N S}$, (Nash and Sutcliffe 1970) was selected to assess the performance of IFAS by inputting boundary conditions to account for the contribution of upstream catchment feeding into each of the 6 sub-basins in the target area and their respective values are reported in Table 2.

$E_{N S}$ values were calculated for each calibration flood events and sub-basin. The average value for all stations and events confounded is -1.16 if no measured discharge data are given as boundary condition and 0.61 if they are given. Without boundary condition, $E_{N S}$ are mostly negative, meaning the mean value of observed data is performing better as a predictor than our model. However, if measured discharges are input as boundary condition, the performance of the model increases notably until becoming acceptable or even very satisfactory with values over 0.9 (The results show that PWRI-DHM is able to simulate rainfall-runoff 
Sugiura et al., Challenges on modelling large river basin with scare data availability: case study of Indus upper catchment.

processes provided sufficient data are given. We will now focus the discussion on the results from the configuration with measured discharges input as boundary conditions to each sub-basin.

For 1988, the performance of the model is low in general ( $E_{N S}$ even negative for Kalabagh). The limited number of rain gauges for 1988 may explain the poor results. Hence, rainfall input being insufficient, the simulated discharges are also insufficient. Moreover, for Kalabagh, $E_{N S}$ is low (0.45) for 1988 and better for 1997 and 2010 (0.85 and 0.83, respectively). Fig 4 compares hydrographs at Kalabagh obtained from simulation with or without boundary condition given in Tarbela. It appears that the two excessive peaks in the end of July 1988 are the results of uncertainties on rainfall data for sub-basin 3 for 1988.

Table 2 Nash-Sutcliffe Efficiency after calibration and for the validation events firstly with discharges given as boundary condition (white background) and secondly without boundary condition (grey background).

(Score under 0.5 are presented in red)

\begin{tabular}{|c|c|c|c|c|c|c|c|c|c|c|c|c|}
\hline \multirow[b]{3}{*}{ Taunsa } & \multicolumn{6}{|c|}{$\begin{array}{c}\text { Calibration: average } E=0.61 \text { with } \\
\text { discharge input, } E=-1.16 \text { without } \\
\text { discharge input. }\end{array}$} & \multicolumn{6}{|c|}{$\begin{array}{l}\text { Validation: average } E=0.67 \text { with discharge } \\
\text { input, } E=-1.60 \text { without discharge input. }\end{array}$} \\
\hline & \multicolumn{2}{|c|}{1988} & \multicolumn{2}{|c|}{1997} & \multicolumn{2}{|c|}{2010} & \multicolumn{2}{|c|}{1992} & \multicolumn{2}{|c|}{1994} & \multicolumn{2}{|c|}{2012} \\
\hline & 0.89 & -0.03 & 0.86 & -2.40 & 0.96 & -0.03 & 0.85 & -1.46 & 0.93 & 0.55 & $\begin{array}{c}0.1 \\
0 \\
\end{array}$ & -16.39 \\
\hline Chasma & 0.82 & -0.29 & 0.86 & -0.61 & 0.95 & 0.03 & 0.92 & -1.76 & 0.93 & 0.65 & $\begin{array}{c}0.9 \\
5\end{array}$ & -6.15 \\
\hline Kalabagh & -0.27 & -0.34 & 0.85 & 0.01 & 0.83 & -0.03 & 0.91 & -1.80 & 0.86 & 0.63 & $\begin{array}{c}0.8 \\
9\end{array}$ & -4.20 \\
\hline Kabul & 0.34 & 0.73 & 0.69 & 0.69 & 0.28 & 0.48 & NoData & $\begin{array}{c}\mathrm{NoD} \\
\text { ata }\end{array}$ & 0.75 & -0.57 & $\begin{array}{c}0.7 \\
1\end{array}$ & -4.22 \\
\hline Tarbela & 0.38 & -0.45 & 0.78 & -0.18 & 0.73 & -0.59 & 0.8 & -3.95 & 0.92 & -0.23 & $\begin{array}{c}0.9 \\
2\end{array}$ & 0.06 \\
\hline Besham & 0.2 & -0.62 & 0.79 & -0.25 & 0.76 & -0.67 & 0.72 & -4.49 & 0.9 & -0.41 & $\begin{array}{c}0.9 \\
3 \\
\end{array}$ & -0.05 \\
\hline P.Bridge & 0.71 & -0.25 & 0.85 & -0.06 & 0.52 & -1.18 & 0.56 & -6.53 & -1.18 & -0.38 & $\begin{array}{c}0.0 \\
2 \\
\end{array}$ & -0.02 \\
\hline
\end{tabular}

\subsection{Discussion on calibration and validation}

Discussion on calibration results (Table 2 the cells with white background) for 1988, 1997 and 2010. In this section, only the simulation cases with low performance $\left(E_{N S}<0.5\right)$ are discussed.

For Kabul, $E_{N S}$ values are lower than for other stations, with an average of 0.56 . This is the result of uncertainties on rainfall data. Indeed, as reported in section 2, over the Kabul river basin, there is only one rain gauge station covering an area over $52,636 \mathrm{~km}^{2}$. Therefore, measured discharges at Warsak dam were given as boundary conditions. On purpose, we did not try to fine-tune more as it would undermine results. And for 2010, the rain gauge was washed away during the highest moment of the flood (PMD personal communication) and therefore, there is no data to compare the simulation with.

The calibration results are deemed to be satisfactory and we will now consider the performance of the model for the flood events 1992, 1994 and 2012 to validate the calibration process.

Discussion on validation results (Table 2 the cells with white background) for 1992, 1994 and 2012.

A part from P. Bridge where snowmelt contribution is not negligible, $E_{N S}$ are satisfactory (total average of 0.82 without P. Bridge). The model manages to simulate properly the trends (increase or decrease) according to rainfall input. In particular, peak timing and intensities are correct.

For 2012, the poor performance of the model for $E_{N S}$ for Taunsa was unexpectedly low (0.10). However, after comparing the discharges at Taunsa for 1992, 1994 and 2012 (Fig 5), it appears that in 2012, discharges were significantly lower (almost 50\% lower) than those during the other years. Moreover, the model response to rainfall is appropriately simulated and the trends are properly reproduced; however, the amount of water discharged is recurrently $2,000 \mathrm{~m}^{3} / \mathrm{s}$. This points out the strong dependency of the model to the availability and quality of measured discharge data. 
Sugiura et al., Challenges on modelling large river basin with scare data availability: case study of Indus upper catchment.

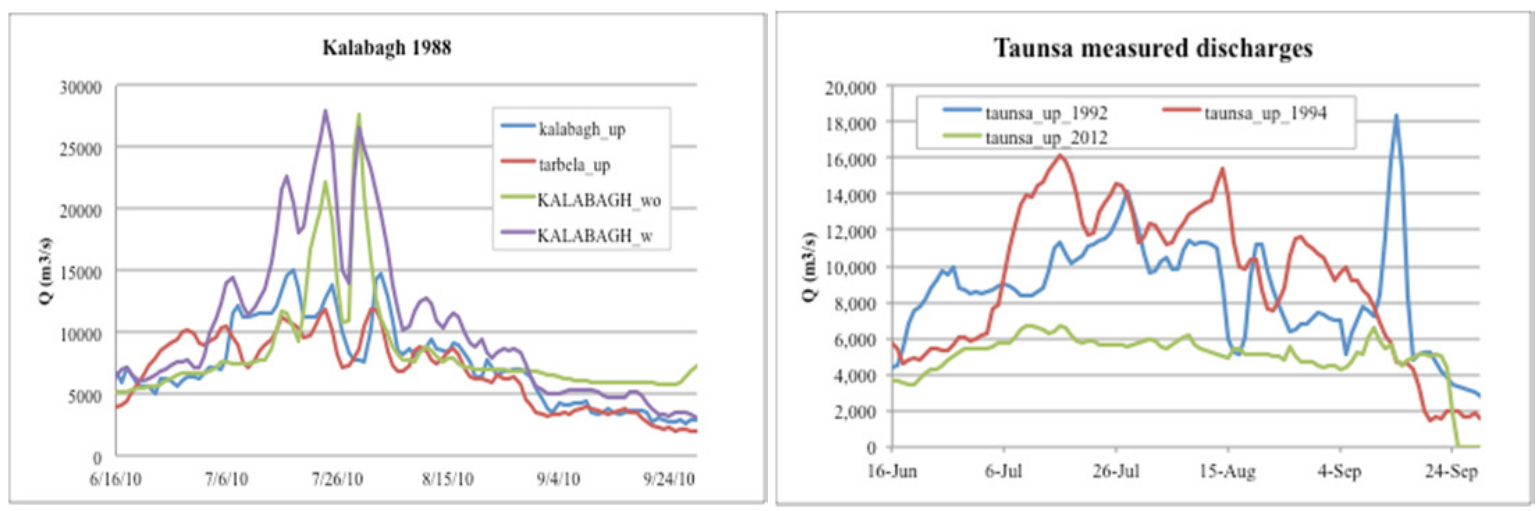

Figure 4 (left) Comparison between simulation of discharges in Kalabagh with (KALABAGH_w) or without (KALABAGH_wo) input of Tarbela discharges (tarbela_up) against observed data (kalabagh_up ) for 1988.

Figure 5 (right) Comparison of observed discharges in Taunsa for the year 1992, 1994 and 2012 from the 15 th of June until 1 st of October of each year.

\section{CONCLUSION}

Despite the lack of rainfall data and local data on soil hydraulics, it was possible to satisfactorily calibrate a PWRI-DHM 3-layer tank, a distributed physically based rainfall-runoff model, which can now be part of a flood forecasting system in the Indus River. However the model performance is strongly dependent on the availability and quality of measured discharge data at the upstream boundary because precipitation data, both rain and snow are not adequate. Because the flow concentration times in Indus system are of days' order of magnitude, dependence on measured discharge data does not impede the model use efficiency as a flood forecasting system.

\section{ACKNOWLEDGMENTS}

This study is the result of a UNESCO project "Strategic Strengthening of Flood Warning and Management Capacity of Pakistan" funded by JICA. The authors acknowledge and thank also the cooperation of project partners, in particular Pakistan Meteorological Department for providing and facilitating all existing data in their organization and beyond.

\section{REFERENCES}

Allen, R., L. Pereira, D. Raes, and M. Smith (1988) "Crop Evapotranspiration: Guidelines for Computing Crop Water Requirements. Paper 56." Irrigation and Draianage, FAO, Rome, Italy, 300.

Beven, K., and J. Freer. (August 2001) "Equifinality, data assimilation, and uncertainty estimation in mechanistic modelling of complex environmental systems using the GLUE methodology." Journal of Hydrology 249, no. 1-4: 11-29.

FAO/IIASA/ISRIC/ISSCAS/JRC.(2009) "Harmonized World Soil Database (version 1.1).." FAO, Rome, Italy and IIASA, Laxenburg, Austria.

Federal Floods Commission.(2013) Annual Flood Report 2012.Federal Floods Commission, Government of Pakistan...

Flood Forecasting Division. River systems and Flood Routing Model Retrieved from http://www.pmd.gov.pk/FFD/index_files/frm.htm.

Fujita, K., and et al. (2006) Project Research Report 299: "Watershed/Urban Regeneration in Accord with Nature" Technical Report (II). River Environment Laboratory, NILIM, Tsukuba, Japan: NILIM.

Inam, A., et al. (2007) "16: The Georgraphic, Geological and Oceanographic Setting of the Indus River." In Large Rivers: Geomorphology and Management”, by A. Gupta, 712. John Wiley and Sons, Ltd.

ISCGM. (n.d.). www.iscgm.org. Retrieved from www.iscgm.org.

Kanamitsu, M., et al. (Nov 2002) "NCEP-DEO AMIP-II Reanalysis (R-2)." Bulletin of the American Meteorological Society. 1631-1643.

Kelleners, T.J., J. Beekma, and M.R. Chaudhry. (October 1999) "Spatially variable soil hydraulic properties for simulation of field-scale solute transport in the unsaturated zone." Geoderma 92, no. 3-4: 199-215.

Krause , P., D. P. Boyle , and F. Baese. (2004) "Comparison of different efficiency criteria for hydrological model assessment." Edited by K. Bongartz, and W.-A. Flügel P. Krause. the 8th Workshop for Large Scale Hydrological Modelling. Oppurg: Advances in Geosciences. 89-97. 
Sugiura et al., Challenges on modelling large river basin with scare data availability: case study of Indus upper catchment.

Maidment, D.R. (1993) Handbook in Hydrology. McGraw-Hill.

Nash, J. E. , and J. V. Sutcliffe. (1970) "River flow forecasting through conceptual models, Part I - A discussion of principles." Journal of Hydrology. 10: 282-290.

Sugawara, M., and F. Maruyama. (1956) "A method of prevision of the river discharge by means of a rainfall 555 models." Symposia Darcy. Dijon: International Association Science Hydrological Publication, 42 , 3 : 556. 71-76.

Sugiura, T., Fukami, K., Fujiwara N., Hamaguchi, K., Nakamura, S., Hironaka, S., Nakamura, K., Wada, T., Ishikawa, M., Shimizu, T., Inomata, H., Itou, Z. (2010) "Experimental application of flood forecasting system (IFAS) using satellite-based rainfall." Ninth International Conference on Hydroingormatics. Tianjin, China: HIC2010. 1786-1793.

Thiessen, A.H. (1911) "Precipitation averages for large areas." Monthly Weather Review, 39, no. 7: 10821084.

WAPDA. (2011) Tarbela Dam Project - Flood Management Manual - Survey and Hydrology. Islamabad, WAPDA, Government of Pakistan.

WMO. (2008) Guide to Hydrological Practices. Sixth Edition. No. 168. Geneva: WMO. 